\title{
Effective Management of Own Funds in Polish Cooperative Banks
}

\author{
Rafał Balina, Olaf Kowalski, Jerzy Różyński \\ Warsaw University of Life Sciences - SGGW, Warsaw, Poland
}

\begin{abstract}
Today cooperative banks belong to the most significant financial institution in the world. Moreover, they can compete with commercial banks. The own funds of the cooperative bank are important in their activity. The main goal of this paper is to investigate how much the level of the own funds of the Polish cooperative banks influenced their efficiency. The research pertained to operating cooperative banks in Poland. The following measures of the efficiency were used in the research: return on Equity (ROE), net profit, index C/I, and financial margin. The results of the study indicate that banks from the Quartile III (highest aggregate own funds), had the highest net profits, the highest ROE, the lowest C/I value, the lowest ROE, and the lowest financial markups. On this basis, it remains to be recommended that banks of highest aggregate own funds continue expansion of own funds which will increase lending capacity and subsequently contribute to higher effectiveness.
\end{abstract}

Keywords: cooperative bank, own funds, effectiveness

\section{Introduction}

There are 572 cooperative banks in Poland distributed throughout, employing over 32,000 employees with about 4,000 branches servicing over 10 million clients. The next few years will challenge the cooperative (co-op) banking sector in the areas of social market and legal shifts which may influence its market share of the Polish and European banking market.

Looking at the current activities of Poland's co-op banks, there is a noticeable change in management techniques and approaches to commercial activity. The Polish co-op banks have in recent years modified their profiles exemplified in the guidelines for granting loans, offered services and products and marketing efforts (Zhou, Ming, \& Ou, 2013, pp. 477-482). Yet the range and pace of these changes are contingent on the economic/financial returns of the banks, which in turn, are dependent on aggregate own funds. Therefore it seems pragmatic to determine the relationship between a bank's aggregate own funds and those funds' effectiveness, where this information is strategic for the expansion of the Polish co-op banking sector (Flejterski, 2008). A separate issue is the answer to the question as how co-op banks should increase their own

Rafał Balina, Ph.D., Department of Economics and Organization of Enterprises, Faculty of Economic Sciences, Warsaw University of Life Sciences - SGGW.

Olaf Kowalski, Ph.D. Candidate, Department of Economics and Organization of Enterprises, Faculty of Economic Sciences, Warsaw University of Life Sciences - SGGW.

Jerzy Różyński, Ph.D. Candidate, Department of Economics and Organization of Enterprises, Faculty of Economic Sciences, Warsaw University of Life Sciences - SGGW.

Correspondence concerning this article should be addressed to Rafał Balina, Nowoursynowska str. 166. 02-787 Warsaw, Poland. E-mail: rafal_balina@sggw.pl. 
funds to accomplish established targets.

Currently co-op banks are of those important economic institutions supporting local and regional development. Polish cooperative banking was initially the only social institution opposed to the economic exploitation of poverty stricken classes. The ability of adjustment to existing political and socio-economic conditions, along with appropriate strategies of operation has contributed to the contemporary image of co-op banks. In addition, they are intermediaries for European Union (EU) funds, disbursing money in accordance with investment programs for rural areas, and are recognized as financial partners to local governments along with small and medium businesses (Juszczyk, 2012, pp. 35-36). To a greater degree, these institutions are located outside metropolitan areas accounting for the major clientele of co-op banks being from rural and suburban municipalities.

It is pertinent to notice that co-op banks, regardless of their charters, function in a specific and dynamic market. Pursuing optimal profits is realized with reasonable and acceptable levels of risk, fully guaranteed deposits, and taking the charter in account, supporting community development and local economy (Zaleska, 2002, p. 69). These activities must be modeled on above all effectiveness whose contribution is a competitive market rating (Baltensperger, 1980, p. 32). Conversely, co-op banks must answer to administrative regulations which establish through statute levels of own funds in reference to lending capacity and carried risk. Determining the correlation of these parameters and defining the influence of these funds on the economic and market status of co-op banks are a challenge of strategic meaning (Juszczyk, Balina, Różyński, \& Pochopień, 2013).

Recent experience tied to the financial crisis made the consequences of advancing globalization apparent, of which one element is the growing number, and strength thereof, of contacts and ties between banking systems of various countries (Pinprayong \& Wongsurawat, 2012, pp. 719-728). Banks that undertake various international endeavors necessarily burden themselves — but not only — with higher systemic risk which directly endangers the stability of banking systems that requires pragmatic activity, to increase system security, and balanced conditions of competition. The Basel Committee on Banking Supervision (BCBS) is acting on these issues; however, changes in capital requirements proposed by the committee will impact co-op banks' own funds which are the foundation of their activity (Yalçinkaya \& Aktas, 2013, pp. 186-194).

\section{Research Questions}

In the theoretical precepts of cooperatives, it is expected that a cooperative, as an organized unit, should generate certain societal benefits to the local community (Powell, 1987, p. 26). It reasons that this function obligates cooperative banks as well, since they are a cooperative financial institution. These social benefits can be understood as any profits for bank membership and local community arising from utilizing products and services of the cooperative bank, as well as any subsidies by the bank for investment or community projects whose beneficiary is the local community (Porter \& Kramer, 2006, pp. 2-3). Benefits to members can take the form lower bank product and service costs as compared to the competition or in the form of cooperative bank subsidies to sport, culture, education or even social services. This is why cooperative bank play a key role in regional and local development (Diepenbeek \& De Vries, 2004, p. 125). Over several decades cooperative banks based their activity on the ideals of self-help and mutual support coupled with activity for the benefit of its membership and the local market and community (Altunbasy, Evans, \& Molyneux, 2001, pp. 926-954). It becomes evident that cooperative banks are established, generally, by individuals of the local community, or neighbors who share a profession (or vocation), or people who pursue a common goal (Coase, 1960, pp. 1-43). 
The essence of cooperatives, as cooperative banks, is the deeply rooted awareness of the local community. This article assesses the impact of the own funds in relation to the Polish cooperative banks. This is a crucial question because the cooperative banks as organizations whose goal is not to maximize profit but the activities for local communities in a particular way should manage the capital entrusted to them.

\section{Research Methods}

The research pertained to operating cooperative banks in Poland on December 31, 2005, i.e., 576 banks. During the research, 96 banks were undergoing consolidation (or other transformation) and were thus excluded from the study. Four hundred-eighty banks were taken into consideration and classified according to declining rank of annual balances on December 31, 2005. Next, every other co-op bank on the list, starting with bank number 2 , was chosen, and as a result there were 240 banks in the study group. The time frame for research was eight years, i.e., 2005 to 2012 , inclusive.

Source materials were annual financial reports published in the Monitor Spótdzielczy B, an official publication of Poland's Ministry of Finance, and data of the co-op banks.

One of the more important indicators in assessing effectiveness is net profits-probably the most important. Szustak suggests that increased profits enable increased market value, disbursement of dividends to members, higher bank reliance in the market and establish the degree of self-financed expansion (Farrel, 2010, pp. 253-281). Net profits are an important source of increasing own funds (Szustak, 2009, p. 128). With the above advantages in mind, this indicator was chosen in order to determine co-op bank effectiveness. In this effectiveness study, besides net profits (in thousands of PLN), other indicators were used:

- return on equity (ROE);

- return on assets (ROA);

- the $\mathrm{C} / \mathrm{I}$ indicator identifying the ratio between bank operating costs (including amortization) to bank operations adjusted for results for other bank activities;

- profit margin, i.e., the resultant quotient from interest and average working capital.

The effectiveness analysis was performed within the framework of defined parameters and the banks were divided into groups according to the quartile method, i.e., Quartile I incorporated $25 \%$ of the banks having the lowest level results of the analyzed criteria; Quartile III incorporated 25\% of the banks having the highest level results of the criteria; and Quartile II incorporated the remaining 50\% of the banks having mean level results between Quartile I and III.

The economic effectiveness study of the co-op banks was carried out in a number of phases.

The first phase of research assessed the correlation coefficient between examined factors. Next, if the correlation was significant but low $(\geqslant 0.2)$, estimation of the linear regression function for net profit was performed in reference to a given characteristic (Ramanathan, 1995, p. 138). The next phase assessed the relevance of the valuated linear regression function using the $t$-Student and $F$ tests (Pindyck \& Rubinfeld, 1998, p. 64). The last phase of assessing the linear regression model was the substantive assessment of the regression coefficient value.

\section{Research Results}

In accordance with the adopted procedure, Table 1 presents the results pertaining to the dependence between net profits and levels of aggregate own funds of the examined banks. 
Table 1

Net Profits Linear Regression Models Regarding Aggregate Volume of Own Funds Per Bank (thousands PLN)

\begin{tabular}{|c|c|c|c|c|c|c|c|c|}
\hline \multirow{2}{*}{ Specification } & \multicolumn{8}{|l|}{ Years } \\
\hline & 2005 & 2006 & 2007 & 2008 & 2009 & 2010 & 2011 & 2012 \\
\hline Correlation coefficient & 0.8621 & 0.8532 & 0.9011 & 0.8909 & 0.8826 & 0.8288 & 0.9568 & 0.8979 \\
\hline Coefficient of determination & 0.743195 & 0.727881 & 0.811946 & 0.739488 & 0.778928 & 0.686898 & 0.915385 & 0.858068 \\
\hline Constant & 104.390 & 101.706 & -174.627 & -18.6239 & -46.9762 & 85.1297 & -207.819 & -647.231 \\
\hline Regression coefficient & 0.14369 & 0.120819 & 0.177803 & 0.179071 & 0.119798 & 0.0997770 & 0.139586 & 0.163902 \\
\hline t-Student statistics value ${ }^{*}$ & 13.16 & 36.24 & 40.92 & 42.42 & 43.71 & 34.10 & 46.98 & 35.12 \\
\hline F statistic value ${ }^{*}$ & $1,420.57$ & $1,277.45$ & $1,674.21$ & $1,799.52$ & $1,910.95$ & $1,162.48$ & $2,206.92$ & $1,233.304$ \\
\hline
\end{tabular}

Notes. " Critical value for $t$-Student test for $n=238$ and $\alpha=0.05$ is $t^{*}=1.65128$; critical $F$ test value for $m 1=1, m 2=238, \alpha=$ 0.05 is $F^{*}=5.88083$.

The analysis of the entries in Table 1 points to a strong connection between net profits and levels of aggregate own funds in co-op banks indicated by a high value in the correlation coefficient, over 0.8532; and a high value in the coefficient of determination, over 0.686 . This suggests a significant dependency between the studied characteristics. Additionally the $t$-Student test, with its empirical value consistently higher than the critical value for all years considered, confirms the association relevance of levels of own funds and net profits for cooperative banks. The $F$ test also indicates significant and purposeful leverage of aggregate own funds on a co-op banks net profits.

On the basis of linear regression model analysis, it can be surmised that net profits are dependent on aggregate own funds; that if other entries remain fixed, the fluctuation in own funds explains the fluctuation of net profits-in 2010, 68.7\%; in 2012, 91.54\%. Additionally, the presented models show that a 1,000 PLN increase in aggregate own funds stimulates, ceteris paribus (with other things the same), a rise in net profits from 99.77 PLN in 2010, to 179.07 in 2008. This suggests that during a period of loan increases, the value of a co-op bank's own funds raises net profits.

An assessment of the effectiveness in utilizing own funds by quartiles in accordance with defined methodology was also carried out. Table 2 presents the individual quartile values based on bank's aggregate own funds levels.

Table 2

Bank's Aggregate Own Funds (thousands PLN) According to Co-op Bank Quartiles

\begin{tabular}{|c|c|c|c|c|c|c|c|c|c|c|c|c|c|c|c|c|}
\hline \multirow{3}{*}{ Group } & \multicolumn{16}{|l|}{ Year } \\
\hline & \multicolumn{2}{|l|}{2005} & \multicolumn{2}{|l|}{2006} & \multicolumn{2}{|l|}{2007} & \multicolumn{2}{|l|}{2008} & \multicolumn{2}{|l|}{2009} & \multicolumn{2}{|l|}{2010} & \multicolumn{2}{|l|}{2011} & \multicolumn{2}{|l|}{2012} \\
\hline & from & to & from & to & from & to & from & to & from & to & from & to & from & to & from & to \\
\hline Quartile I & & 2,832 & & 3,399 & & 4,134 & & 4,468 & & 5,250 & & 5,674 & & 6,689 & & 7,432 \\
\hline Quartile II & 2,833 & 6,313 & 3,400 & 7,543 & 4,135 & 8,549 & 4,469 & 10,295 & 5,251 & 11,935 & 5,675 & 13,329 & 6,690 & 16,815 & 7,433 & 19,066 \\
\hline Quartile III & 6,314 & & 7,544 & & 8,550 & & 10,296 & & 11,936 & & 13,330 & & 16,816 & & 19,067 & \\
\hline
\end{tabular}

Figure 1 presents the formatting of the average level of net profits in the selected groups of co-op banks based on aggregate own funds. The research shows that banks of the Quartile III display the highest level of aggregate own funds in the years of the study and also show the highest levels of net profits. Banks of the Quartile I however, presented the lowest level of gained net profits. This is caused by the scale of activity by these banks; indeed, the greater a bank's own funds, the larger possible lending activity, which is the largest net 
profits generator for co-op banks. Figure 2 presents the height of ROE (\%) for co-op banks in the category levels of aggregate own funds.

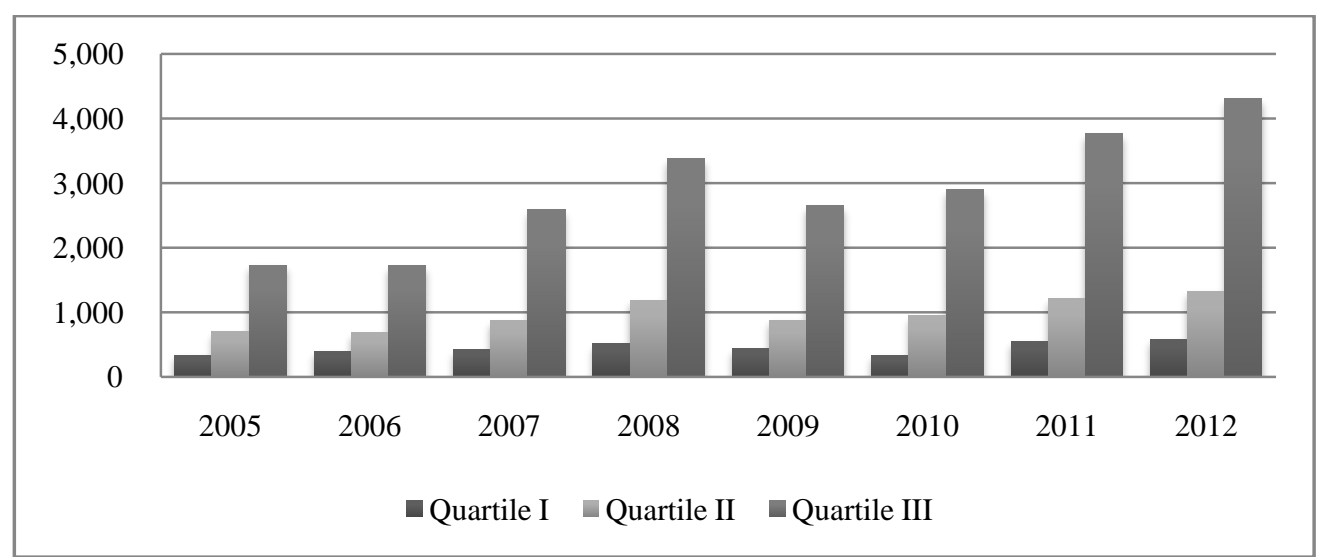

Figure 1. Net profits (thousands PLN) dependency on level of bank's aggregate own funds (thousands PLN).

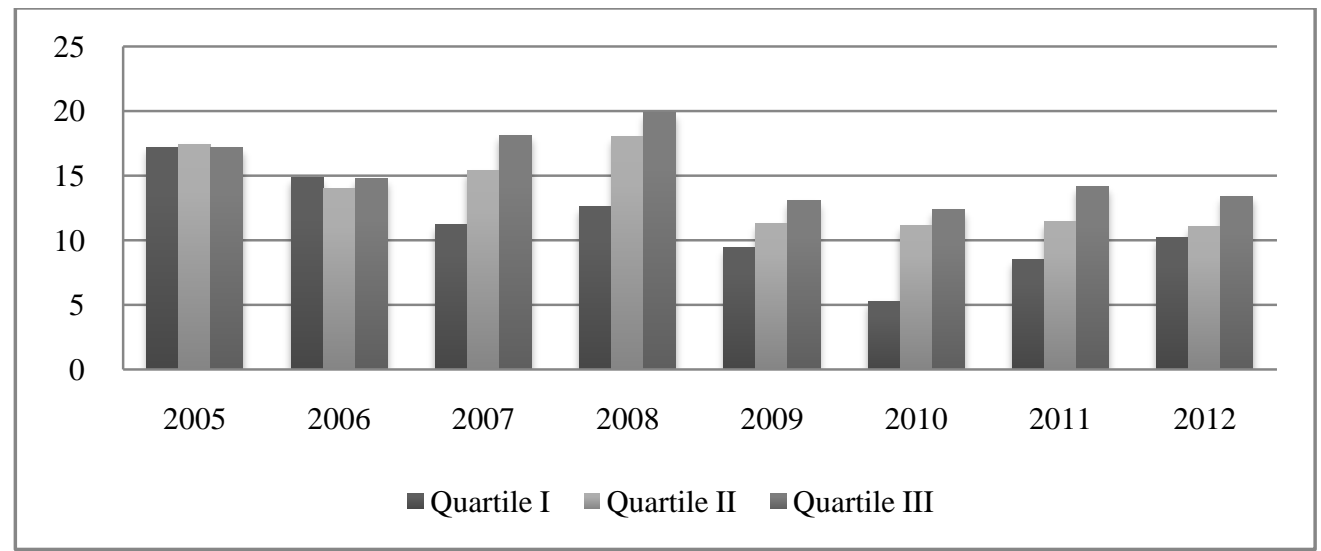

Figure 2. Value of ROE (\%) indicator based on amount of banks' aggregate own funds (thousands PLN).

Cooperative banks which collected the highest levels of aggregate own funds generated the highest ROE values in the years 2007 to 2012, which were higher than the remaining groups of banks. The banks of the Quartile II had next highest ROE values meaning that the higher aggregate own funds of a co-op bank, the higher the return on own funds. For the years 2005 and 2006, the differences between quartile groups were minimal, reaching 0.2 to 0.3 percentage points which indicate a leveled ROE for banks in those years with varying levels of aggregate own funds.

Figure 3 is focusing on the relation of bank operation costs to results of bank activity (C/I). The most effective banks were in the Quartile III which had the lowest value for this indicator and at the same time the costs for bank operation for one unit's banking income results were also the lowest.

For the years 2005-2010, the least effective, as regard to C/I, were the banks of the Quartile II having average levels of own funds. However for 2011-2012, the highest C/I values were banks from the Quartile I, i.e., banks of the lowest own funds group. This may indicate paying close attention to banks of the Quartiles II and I and their reduction of operating costs for the purpose of raising their effectiveness and better utilization of collected aggregate own funds.

Considering the results in Figure 4, it is apparent that with the rise of own funds in the considered co-op 
banks, the return on assets, the banks possessing the lowest aggregate own funds amounts attained the highest ROA values.

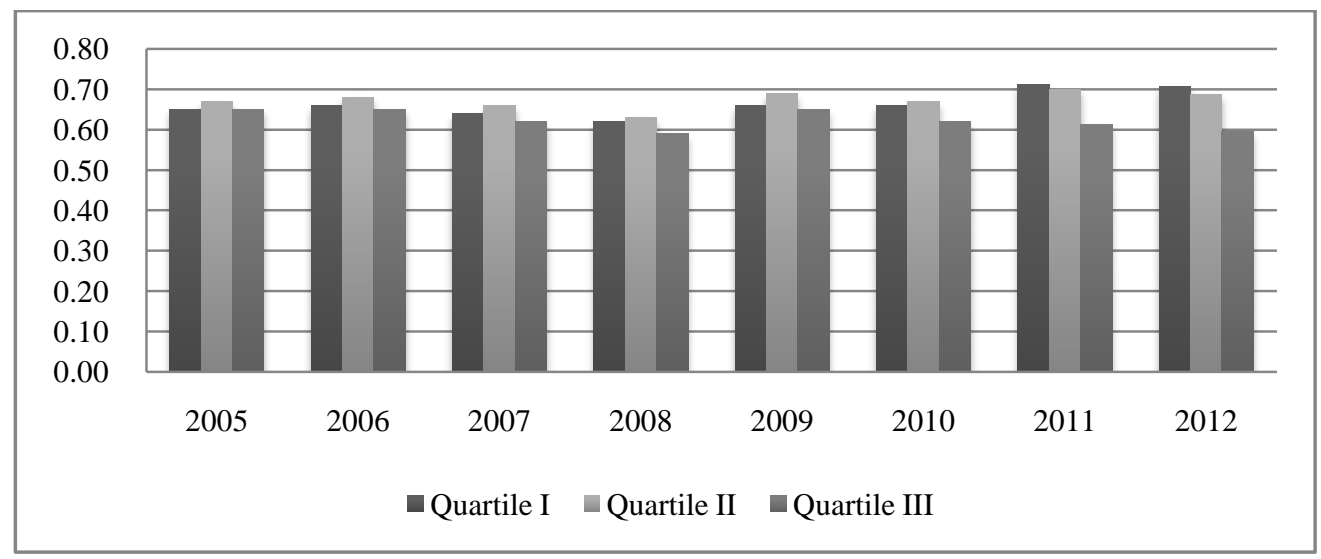

Figure 3. C/I indicator value dependent on amount of aggregate own funds (thousands PLN).

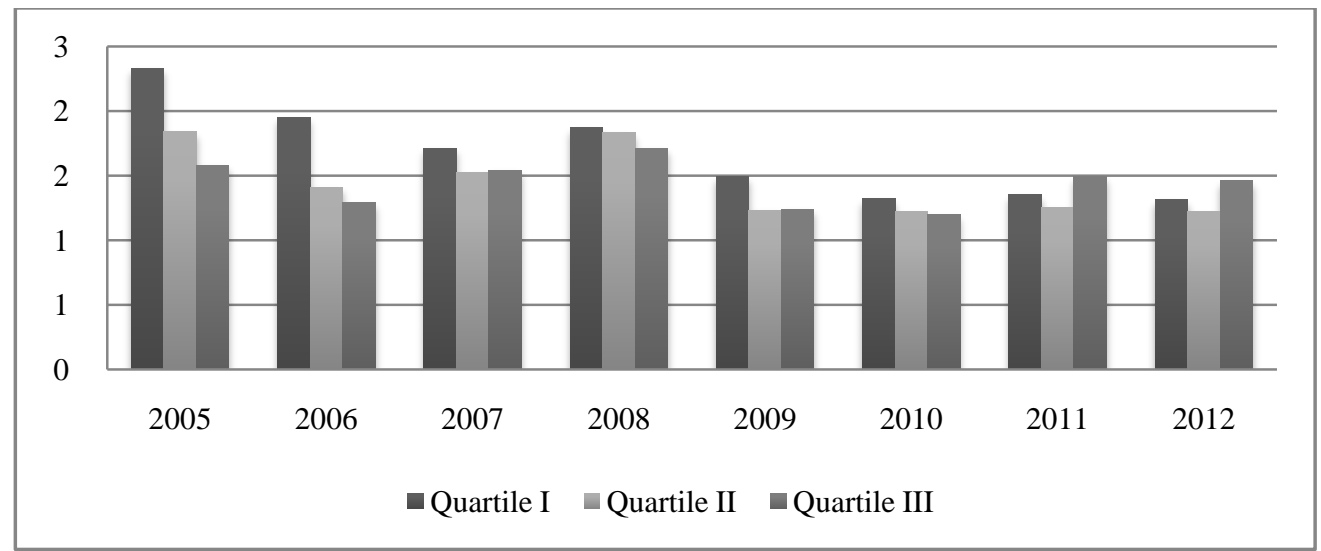

Figure 4. ROA (\%) indicator value dependent on amount of aggregate own funds (thousands PLN).

In connection to this, banks from the Quartile I were admittedly the most effective as regard to returns on general assets, and banks of the Quartile III (highest aggregate own funds) were the least effective in this category. This may be a resultant from the condition that Quartile I co-op banks generally operate in rural and small urban areas where the competition from commercial banks is negligible, and therefore these co-op banks could generate higher profit margins and collect higher commission fees and service charges which could raise ROA effectiveness as compared to the other quartiles.

The formation of the studied banks profit margins with respect to the sum total of collected funds is shown in Figure 5.

The research indicates that the key to improve smaller bank effectiveness (Quartiles I and II) is an increase of own funds and lending capacity growth with advantageous financial conditions for clients. The current maintenance of high margins and service charges may cause a serious market share loss-and decreased effectiveness - especially with growing competition from commercial banking interests. The study indicates that banks in the Quartile III, those with the highest aggregate own funds, generally have the highest net profits and ROE, the lowest C/I value, the lowest ROA level, and the lowest profit margin markup. Based on these indications, it remains to be said that cooperative banks with the highest aggregate own funds should endeavor 
to increase these funds which will increase their aggregate lending capacity and in effect, raise their effectiveness.

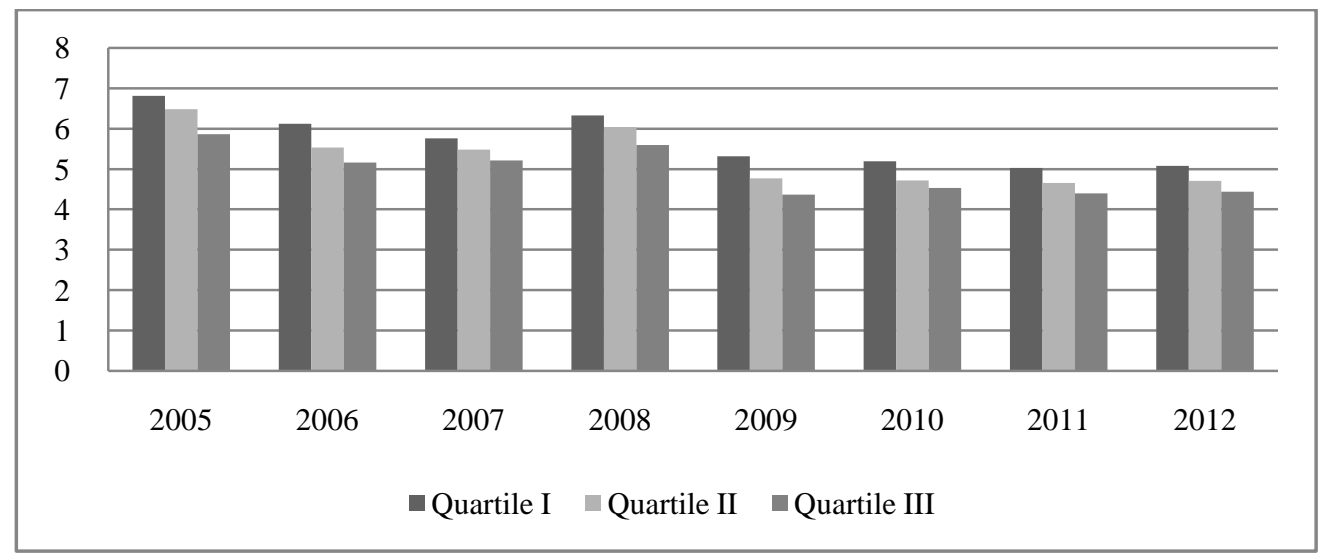

Figure 5. Profit margin values (\%) with respect to the amount of aggregate own funds (thousands PLN).

\section{Conclusions}

On the basis of this research, it can be stated that the key maneuvers for increased effectiveness by smaller and medium banks (Quartiles I and II), are expanding own funds and lending capacity with advantageous economic conditions for client because the current tendencies of maintaining high margin markups and service charges, with increased competition from commercial banks, may result in loss of market share and lowered effectiveness classification. The results of the study indicate that banks from the Quartile III (highest aggregate own funds), had the highest net profits, the highest ROE, the lowest C/I value, the lowest ROE, and the lowest financial markups. On this basis, it remains to be recommended that banks of highest aggregate own funds continue expansion of own funds which will increase lending capacity and subsequently contribute to higher effectiveness.

\section{References}

Altunbasy, Y., Evans, E., \& Molyneux, P. (2001). Bank ownership and efficiency. Journal of Money, Credit \& Banking, 33, 926-954.

Baltensperger, E. (1980). Alternative approaches to the theory of the banking firm. Journal of Monetary Economics, 6, 32.

Coase, R. H. (1960). Problems of social cost. Journal of Law and Ecoomics, 3, 1-43.

Diepenbeek, W. J. J., \& De Vries, Y. B. (2004). Co-operative banking and the social economy in the Netherlands (p. 125). Spain: Banca cooperative y economica social en Europa.

Farrel, M. J. (2010). The measurement of productive efficiency. Journal of the Royal Statistical Society, 120, $253-281$.

Flejterski, S. (2008). Banking in the system of finance, contemporary finances, status and prospects of the development of banking (Bankowość w systemie nauk o finansach, Współczesne finanse. Stan iperspektywyrozwoju bankowości). Toruń.

Juszczyk, S. (2012). Cooperative banking in Poland (Bankowość spółdzielcza w Polsce). Village of Tomorrow (Wieś Jutra), 11/12, s. $35-36$.

Juszczyk, S., Balina, R., Różyński, R., \& Pochopień, J. (2013). Variability of equity and the efficiency of cooperative banks. (Zmienność funduszy własnych a efektywność banków spółdzielczych). Zarzqdzanie i Finanse (Management and Finance), 11(2), 1 .

Pindyck, R. S., \& Rubinfeld, D. L. (1998). Econometric models and economic forecasts (p. 64). Boston: McGraw-Hill International Edition.

Pinprayong, B., \& Wongsurawat, W. (2012). Restructuring and sustainability-corporate strategy of commercial bank in Thailand. Chinese Business Review, 11(8), 719-729. 
Porter, M. E., \& Kramer, M. R. (2006). The link between competitive advantage and corporate social responsibility. Harvard Business Review, 84(2), 2-3.

Powell, W. (1987). The nonprofit sector (p. 26). New Haven: Yale Uniwersity Press.

Ramanathan, R. (1995). Introductory econometrics with applications (p. 138). Sand Diego: Harcourt Brace College Publishers.

Szustak, G. (2009). Equity capital and the safety, efficiency and competitiveness of the bank (Kapitat wlasny a bezpieczenstwo, efektywność i konkurencyjność banku) (p. 128). Katowice: Wydawnictwo Akademii Ekonomicznej w Katowicach.

Yalçinkaya, H. S., \& Aktas, M. A. (2013). Effect of Turkish bank capital structure of Basel II criteria. Chinese Business Review, 12(3), 186-194.

Zaleska, M. (2002). Fundusze własne banków (spółdzielczych)—podstawy prawne i aspekty ekonomiczne. Studia i Prace SGH, Kolegium Zarządzania i Finansów, Warszawa.

Zhou, J., Ming, D., \& Ou, X. (2013). Review on the study of the allocation of corporate control in enterprise theory. Chinese Business Review, 12(7), 477-482. 